Tropical Journal of Pharmaceutical Research April 2016; 15 (4): 759-764

ISSN: $1596-5996$ (print); 1596-9827 (electronic)

(C) Pharmacotherapy Group, Faculty of Pharmacy, University of Benin, Benin City, 300001 Nigeria.

All rights reserved.

Available online at http://www.tjpr.org

Original Research Article

http://dx.doi.org/10.4314/tjpr.v15i4.13

\title{
Determination of antioxidant activity, phenolic contents and antiviral potential of methanol extract of Euphorbia spinidens Bornm (Euphorbiaceae)
}

\author{
Ali Karimi ${ }^{1}$, Marzieh Mohammadi-Kamalabadi ${ }^{2 \star}$, Mahmoud Rafieian-Kopaei ${ }^{3}$, \\ Leila Amjad ${ }^{4}$ and loghman Salimzadeh ${ }^{5}$ \\ ${ }^{1}$ Department of Virology, Medical Plants Research Center, Shahrekord University of Medical Sciences, Shahrekord, ${ }^{2}$ Young \\ Researchers and Elite Club, Falavarjan Branch, Islamic Azad University, Isfahan, ${ }^{3}$ Medical Plants Research Center, \\ Shahrekord University of Medical Sciences, Shahrekord, ${ }^{4}$ Department of Biology, Falavarjan Branch, Islamic Azad University, \\ Isfahan, ${ }^{5}$ Department of Immunology, Cellular and Molecular Research Center, Shahrekord University of Medical Sciences, \\ Shahrekord, Iran
}

*For correspondence: Email: min_mohammady_1365@yahoo.com; Tel: +989131703903

Revised accepted: 3 February 2016

\begin{abstract}
Purpose: This study was aimed to evaluate the antioxidant activity of the methanol extract of Euphorbia spinidens Bornm (Euphorbiaceae) and its effect on Herpes simplex virus type-1 (HSV-1) replication. Methods: The methanol extract of aerial parts of E. spinidens collected from Khorasan State in NorthEastern part of Iran was used in this study. Total phenolic, flavonoid contents and the antioxidant activity were evaluated using Folin-Ciocalteu method, aluminum chloride colorimetric method and $\beta$ carotene-linoleate model system, respectively. Both the cytotoxic and antiviral effects of the crude extract on Vero cell line were determined by quantifying the viability of Vero cells using 3-(4,5dimethylthiazol-2-yl)-5-(3-carboxymethoxyphenyl)-2-(4-sulfophenyl)2H-tetrazolium (MTS) assay.

Results: Total phenolic and flavonoid contents of E.spinidens were $70 \pm 1 \mathrm{mg}$ of gallic acid equivalent/g of dry extract ( $\mathrm{mg} \mathrm{GAE} / \mathrm{g}$ extract) and $49.66 \pm 1.00 \mathrm{mg}$ rutin equivalent/g of dry extract ( $\mathrm{mg}$ RTN/g extract), respectively. Antioxidant activity was $44 \pm 1 \%$ compared with the standard, buthylated hydroxytuloene (BHT). The $50 \%$ cytotoxic concentration $\left(C_{50}\right)$ of the extract on Vero cells was $5.072 \pm$ $0.063 \mathrm{mg} / \mathrm{ml}$ and its antiviral concentration of $50 \%$ effectiveness $\left(E C_{50}\right)$ value was $0.34 \pm 0.003 \mathrm{mg} / \mathrm{ml}$. Conclusion: The findings of this study show that the methanol extract of E. spinidens has high content of phenolic and flavonoid compounds with good antioxidant activity. Furthermore, this extract has significant antiviral effect on HSV-1 probably due to the inhibition of viral replication.
\end{abstract}

Keywords: Antioxidant, Antiviral, Euphorbia spinidens Bornm, Herpes simplex virus

Tropical Journal of Pharmaceutical Research is indexed by Science Citation Index (SciSearch), Scopus, International Pharmaceutical Abstract, Chemical Abstracts, Embase, Index Copernicus, EBSCO, African Index Medicus, JournalSeek, Journal Citation Reports/Science Edition, Directory of Open Access Journals (DOAJ), African Journal Online, Bioline International, Open-J-Gate and Pharmacy Abstracts

\section{INTRODUCTION}

Herpes simplex viruses (HSV) are endemic in through human populations and pathogenic to human. Nucleoside derivative drugs such as acyclovir (AVC), gancyclovir (GCV) and pencyclovir (PCV) have been widely authorized drugs for the treatment of HSV infections [1].
However, the increased and protracted use of these compounds in clinical setting, especially for the therapy of immunocompromised patients, has led to the emergence of viral resistance against most of these drugs [2]. In order to tackle the problem of viral resistance, development of new antiviral products with various mechanisms of action are very much required. 
Medicinal plants have been used for many years for the treatment of human diseases [3] and a number of herbal medicines have been developed into therapeutic agents or have had promising results [4-7]. Plants have the ability to synthesize a wide array of compounds and have long been used as remedies, and many are now being collected and examined in an attempt to identify possible sources of drugs [8-10]. The compounds with natural origin, especially herbal medicines, have been shown to be reliable source of new drugs [11-13].

The Euphorbia is the largest genus in the plant family Euphorbiaceae, containing about 2,000 known species [14]. The plants synthesize large number of diverse secondary metabolites such as terpenoids [15], polyphenols, flavonoids and tannins [16]. Some species of the genus Euphorbia have been exploited as medicinal plants for the treatment of skin diseases, migraine, gonorrhea and intestinal parasites and as wart cures [17]. Researchers have shown that Euphorbia species have antiproliferative activity, cytotoxicity, antipyretic-analgesic activity and also inhibitory activity on the HIV-1 infection [18]. Therefore, this study was aimed to evaluate both antioxidant and anti-HSV-1 activities of the methanol extract of aerial parts of E. spinidens, grown in Iran.

\section{EXPERIMENTAL}

\section{Plant material}

Aerial parts of $E$. spinidens were collected in June 2011 from the wild populations growing in Northern Khorasan Province of Iran. The plant material was authenticated by $\mathrm{Dr}$ Ghorayshol Hosseini of Herbaceous Science Research Center at Ferdowsi University, Mashhad, Iran and a voucher specimen (no. 43033) was deposited at the center's herbarium.

\section{Preparation of plant extract}

Air-dried plant material $(3 \mathrm{~kg})$ was macerated with $15 \mathrm{~L}$ methanol $(96 \%)$ at room temperature (RT) for 5 days. The extract was filtered and concentrated under reduced pressure to yield $134 \mathrm{~g}$ crude extract.

\section{Determination of total phenolic, flavonoid contents and antioxidant activity of the extract}

The total phenolic content of the extract was estimated by Folin Ciocalteu method [19], with some modifications. Briefly, $0.01 \mathrm{~g}$ of dried extracts was dissolved in $10 \mathrm{~mL}$ of $60 \%$ methanol. Thereafter, $0.1 \mathrm{ml}$ of extract solution was added followed by $0.5 \mathrm{ml}$ of $10 \%$ Folin Ciocalteu reagent and after 4 to $8 \mathrm{~min}$ were mixed with $0.4 \mathrm{ml}$ of $7.5 \%$ aqueous sodium bicarbonate. The mixture was kept for $30 \mathrm{~min}$ at RT and then the total phenols were determined by spectrophotometrically at $765 \mathrm{~nm}$ (Unico UV2100 , USA). The results are expressed as $\mathrm{mg}$ of gallic acid equivalents/g of extract (GAEs).

Aluminum chloride colorimetric method was used for flavonoids determination with some modifications [4]. Briefly, $0.01 \mathrm{~g}$ of dried extracts was dissolved in $10 \mathrm{~mL}$ of $60 \%$ methanol. $1 \mathrm{ml}$ of extract solution was mixed with $1 \mathrm{~mL}$ of $2 \%$ aluminum chloride and $6 \mathrm{~mL}$ of $5 \%$ potassium acetate. Following incubation for $40 \mathrm{~min}$. at RT, the absorbance of the reaction mixture was measured at $415 \mathrm{~nm}$ spectrophotometrically. The amount of $2 \%$ aluminum chloride was substituted by the same amount of distilled water in the blank. Total flavonoids were expressed in terms of rutin equivalent (RE) $(\mathrm{mg} / \mathrm{g})$.

Total antioxidant capacity of E. spinidens extracts was assayed using the $\beta$-carotene and linoleic acid [20]. A stock solution of $\beta$-carotene $(0.5 \mathrm{mg})$ in $1 \mathrm{~mL}$ of chloroform, linoleic acid (25 $\mu \mathrm{l})$, and Tween-40 (200 mg) was prepared and chloroform completely evaporated using a vacuum evaporator at $50{ }^{\circ} \mathrm{C}$. Thereafter, $100 \mathrm{~mL}$ of oxygenated water $(30 \mathrm{~min} 100 \mathrm{ml} / \mathrm{min}$ ) were added under vigorous shaking. $2500 \mu \mathrm{l}$ aliquots of this emulsion were added to test tubes and $350 \mu \mathrm{l}$ of the extracts prepared at $2 \mathrm{~g} / \mathrm{l}$ concentrations were added and incubated for 48 $\mathrm{h}$ at room temperature. The same procedure was repeated with BHT (as positive control) and a blank. The absorbance of the solutions was measured at $490 \mathrm{~nm}$. Antioxidant capacities of the extracts were compared with those of BHT and blank.

\section{Cell culture and virus}

African green monkey kidney cell line (Vero cell line, ATCC C102) was kindly provided by Pasteure Institute of Iran. The cells were grown in Dulbecco's Modified Eagle's Medium (DMEM; Sigma, USA) supplemented with $10 \%$ of fetal bovine serum (FBS; Gibco, Germany), 100 $\mu \mathrm{g} / \mathrm{mL}$ of streptomycin, $100 \mathrm{UI} / \mathrm{ml}$ of penicillin and $0.25 \mu \mathrm{g} / \mathrm{mL}$ amphotericin B (Gibco, Germany), at $37{ }^{\circ} \mathrm{C}$ and $5 \% \mathrm{CO}_{2}$. The same medium containing $2 \%$ PBS was used for cytotoxicity and antiviral assays. HSV-1 (HSV-1, KOS strain) was kindly provided by Department of virology, University of Tarbiat Modares, 
Tehran, Iran. Virus stock was prepared by infection of confluent monolayer Vero cells in 75 $\mathrm{cm}^{2}$ culture flasks using DMEM medium with $2 \%$ $\mathrm{FBS}$, at $37{ }^{\circ} \mathrm{C}$ in $5 \% \mathrm{CO}_{2}$. Virus titer was determined by cytopathic effect (CPE) of HSV-1 in Vero cells and was expressed as the $50 \%$ Tissue Culture Infective Dose $\left(\mathrm{TCID}_{50}\right)$ per $\mathrm{ml}$ using the formula of Spearman-Karber [21].

\section{Cytotoxicity assay}

Prior to the investigation of anti-HSV-1 activity, the cytotoxic effect of the extract was determined. Briefly, Vero cells were seeded onto 96-well plates with a concentration of $3.5 \times 10^{5}$ cells/well with final volume of $100 \mu \mathrm{l}$ per well. After incubation at $37^{\circ} \mathrm{C}$ with $5 \% \mathrm{CO}_{2}$ for $24 \mathrm{~h}$, when the cell monolayer was confluent, the cell culture medium of cells aspirated and washed with PBS. Extracts were serially diluted with the culture medium supplemented with $2 \%$ serum to reach the various concentrations. Negative control dilution of dimethyl sulphoxide (DMSO) at $0.1 \%$ was also included.

Cells were incubated with $100 \mu \mathrm{L} /$ well of various concentrations of the extract or DMSO (in triplicates). After incubation at $37{ }^{\circ} \mathrm{C}$ with $5 \%$ $\mathrm{CO}_{2}$ for 3 days, MTS [3(4,5 dimethylthiazol2yl)5(3carboxymethoxyphenyl)-2(4-sulfophenyl)2H-tetrazolium] (Cell Titer 96; Promega, USA) was added to each well with a volume of $20 \mu \mathrm{L}$. The trays were further incubated for $2 \mathrm{~h}$ to allow MTS production. The absorbances were determined with an ELISA reader (StataFax 2100, USA) at a test wavelength of $490 \mathrm{~nm}$. Data were calculated as the percentage of toxicity using Eq 1 .

Toxicity $(\%)=\{100-($ At $/ A s) 100\}$

where At and As refer to the absorbance of the test and control, respectively [21]. The $50 \%$ cytotoxic concentration $\left(\mathrm{CC}_{50}\right)$ was defined as the cytotoxic concentration of the crude extract by regression analysis.

\section{Antiviral assay}

The virus induced cytopathic effect (CPE) was defined by MTS method. Approximately, $5 \times 10^{5}$ Vero cells/well were seeded onto 96-well plates with final volume of $100 \mu \mathrm{L}$ per well and cultured for $24 \mathrm{~h}$ at $37^{\circ} \mathrm{C}$. When the cell monolayers were confluent, the medium was removed from the wells and $100 \mu \mathrm{L}$ of test virus $\left(100 \mathrm{TCID}_{50}\right)$ was added and incubated for another $2 \mathrm{~h}$. Various non-cytotoxic concentrations ( $\leq \mathrm{CC}_{50}$ values) of the crude extract were then added to culture wells in triplicate test. The maximum concentration of DMSO $(0.1 \%)$ was used as a negative control. Aciclovir (9-(2hydroxyethoxymethyl; Sigma, USA) was used as a positive control for HSV-1. After incubation at $37^{\circ} \mathrm{C}$ with $5 \% \mathrm{CO}_{2}$ for $72 \mathrm{~h}$, MTS was added to each well with a volume of $20 \mu \mathrm{L}$. The trays were renewed incubated for $2 \mathrm{~h}$ to allow MTS production. The absorbances were determined with an enzyme-linked immunosorbent assay (ELISA) reader (Stata Fax 2100, USA) at a test wavelength of $490 \mathrm{~nm}$. Viral inhibition rate (V) was estimated as in Eq 2 [13].

$V=(A t v-A c v) /(A c d-A c v) 100$

where Atv is the absorbance of the test compounds with virus infected cells. Acv and Acd are the absorbance of virus control and of cell control, respectively. The procedure was carried out three times. The $50 \%$ effectiveness concentration $\left(\mathrm{EC}_{50}\right)$ was determined from a curve relating inhibition to the concentration of the extract by regression analysis. Selectivity index (SI), as a marker of antiviral activity, was determined as the ratio of $\mathrm{CC}_{50}$ to $\mathrm{EC}_{50}$.

To analyze the dose-dependent effect of the test drugs on infected Vero cells, different concentrations of the extract was added to HSV1 infected Vero cell culture in triplicate. After 23 days MTT assay was carried out to determine the inhibition of infection caused by the HSV, as described previously [22].

\section{Time-course anti-virus analysis}

Time-course analysis was carried out to investigate the period of time (stage) during which, the extract inhibits HSV-1 replication. This experiment, in which HSV-1 infected cells were treated with different doses of the extract at $1 \mathrm{~h}$ before and $24 \mathrm{~h}$ after the infection, was carried out according to previously described procedures with minor modifications [21]. In brief, approximately, $5 \times 10^{5}$ Vero cells/well were seeded onto 96-well plates with final volume of $100 \mu \mathrm{L}$ per well and cultured for $24 \mathrm{~h}$ at $37^{\circ} \mathrm{C}$. When the cell monolayer's were confluent, the medium was removed from the wells and $100 \mu \mathrm{L}$ of virus (100 TCID 50 per well) was added and incubated for another $2 \mathrm{~h}$. Various non-cytotoxic concentrations ( $\leq \mathrm{CC}_{50}$ values) of crude extract were added to culture cells in triplicate at various times pre-infection $(-1 \mathrm{~h})$, co-infection $(0 \mathrm{~h})$ or post-infection (2, 4, 8 and 24 h). HSV-1(100 $\mathrm{TCID}_{50}$ per well) was inoculated onto confluent monolayers of Vero cells for $2 \mathrm{~h}$. After $72 \mathrm{~h}$, MTS test and antiviral activity were carried out as previously explained. 


\section{Statistical analysis}

All experiments were carried out in triplicate. $\mathrm{EC}_{50}$ and $\mathrm{CC}_{50}$ values were calculated using dose-response analyses and related models with linear regression.

\section{RESULTS}

Total phenolic and total flavonoid contents of crude methanolic extract of $E$. spinidens were 70 $\pm 1 \mathrm{mg} \mathrm{GAE} / \mathrm{g}$ extract and $49.66 \pm 0.996 \mathrm{mg}$ $\mathrm{RTN} / \mathrm{g}$ extract respectively. Also, the crude methanolic extract of $E$. spinidens had lower antioxidant activity than $\mathrm{BHT}$ as reference antioxidant (Table 1).

MTS assay was used to determine both cytoxicity and antiviral activity of the tested agents. The results demonstrated that the $\mathrm{CC}_{50}$ and $\mathrm{EC}_{50}$ of crude methanolic extract of $E$. spinidens were $5.072 \pm 0.063$ and $0.34 \pm 0.003$ $\mathrm{mg} / \mathrm{ml}$ respectively. Moreover, the obtained results based on $\mathrm{EC}_{50}$ value and selectivity index (SI) revealed that the crude methanolic extract inhibited HSV-1 (Table 2).

Time course analysis was carried out with crude methanolic extract to investigate the mechanism of antiviral activity. Inhibition was evaluated by MTS assay at $1 \mathrm{~h}$ before to $24 \mathrm{~h}$ after virus infection and of treatment with different doses of crude extract and represented as percentage inhibition. The results revealed that crude methanolic extract of $E$. spinidens at $5 \mathrm{mg} / \mathrm{ml}$ concentration exhibited the highest inhibition against HSV-1 infection within $2 \mathrm{~h}$ post-infection, which was during the early period of virus replication (Figure 1).

Table 1: Antioxidant activity and total phenolic and flavonoid contents of E.spinidens methanolic extract.

\begin{tabular}{lccc}
\hline Sample & $\begin{array}{c}\text { Total phenolics }^{a} \\
\text { ( }^{2} \text { g GAE/g) }\end{array}$ & $\begin{array}{c}\text { total flavonoids }^{{ }^{a}} \\
\text { (mg RTN/g) }\end{array}$ & $\begin{array}{c}\text { Antioxidant activity }^{\text {ab }} \\
\text { (\%) }\end{array}$ \\
\hline Extract & $70.03 \pm 1.12$ & $49.66 \pm 0.996$ & $44.04 \pm 1.02$ \\
BHT & - & - & $90.06 \pm 0.01$ \\
\hline
\end{tabular}

mg GAE/g: $\mathrm{mg}$ of gallic acid equivalent/g of dry extract, $\mathrm{mg} \mathrm{RTN} / \mathrm{g}: \mathrm{mg}$ rutin equivalent/g of dry extract, $\mathrm{BHT}$ : Buthylated Hydroxytuloene; ${ }^{a}$ Values are given as mean $\pm S D(n=3) ;{ }^{b} \beta$-carotene-linoleate model

Table 2: Assessment of anti-HSV-1 activity of E.spinidens methanolic extract by MTS assay

\begin{tabular}{lccc}
\hline Test drug & $\begin{array}{c}\mathbf{C C}_{50}{ }^{a} \\
(\mathbf{m g} / \mathbf{m l})\end{array}$ & $\begin{array}{c}\mathrm{EC}_{50}{ }^{a} \\
(\mathbf{m g} / \mathbf{m l})\end{array}$ & $\begin{array}{c}\text { Selectivity index } \\
(\mathbf{S I}){ }^{a b}\end{array}$ \\
\hline Extract & $5.072 \pm 0.063$ & $0.34 \pm 0.003$ & 14.917 \\
Acyclovir & $>5$ & $0.028 \pm 0.001$ & $>178.571$ \\
\hline
\end{tabular}

${ }^{a}$ Values are given as mean \pm S.D $(n=3) ;{ }^{b}$ Selectivity index $(\mathrm{SI})=\mathrm{CC}_{50} / \mathrm{EC}_{50} . \mathrm{CC}_{50}: 50 \%$ cytotoxic concentration on Vero cells; $\mathrm{EC}_{50}: 50 \%$ effectiveness concentration

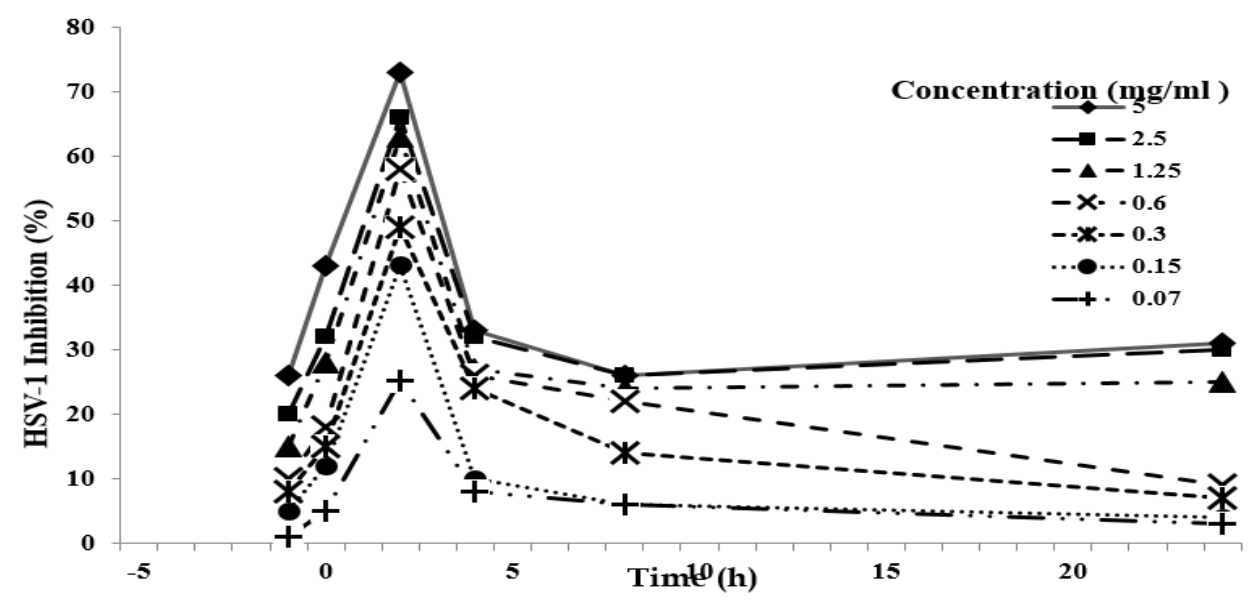

Figure 1: Inhibitory effect of adding methanol extract of $E$. spinidens at various times of herpes virus (HSV-1) to Vero cells. Various concentrations of E. spinidens methanolic extract were added with the HSV-1 infected Vero cells at various times period like pre-infection $(-1 \mathrm{~h})$, co-infection $(0 \mathrm{~h})$ or post-infection $(2-24 \mathrm{~h})$. After 3 days of incubation at $37^{\circ} \mathrm{C}$, inhibition was evaluated by MTS assay and expressed as the inhibition percentage. Each bar represents the Mean \pm SE of three independent experiments 


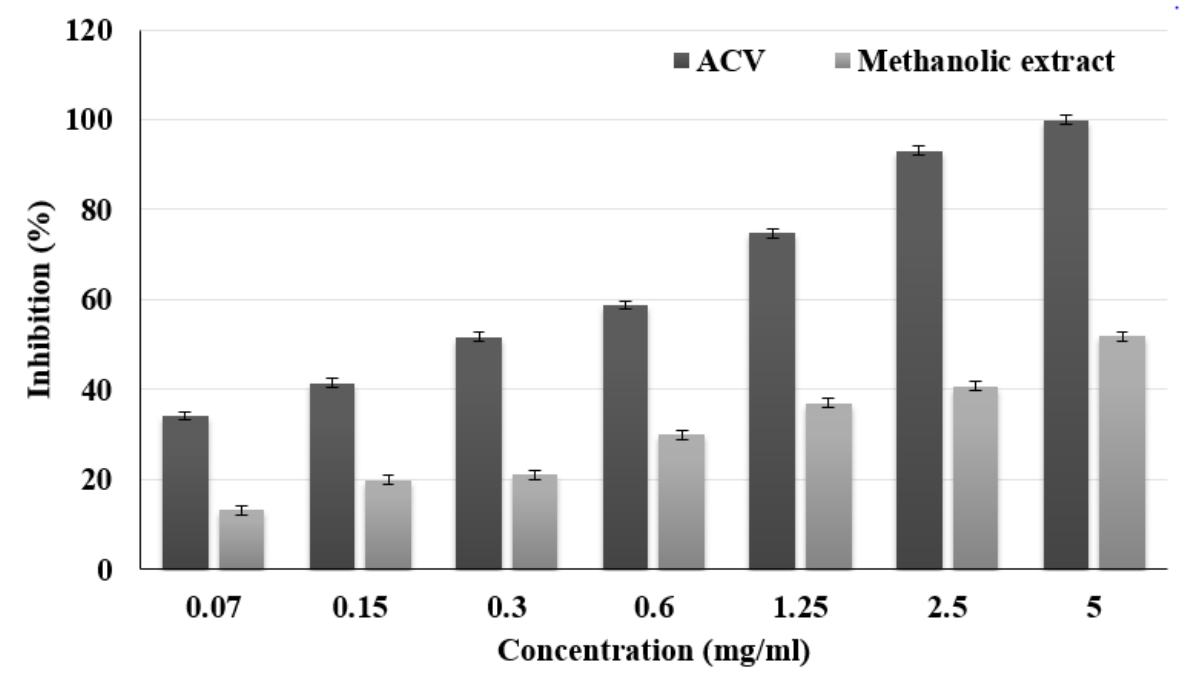

Figure 2: Dose-dependent effect of antiviral activity induced by $E$. spinidens extract. Various concentrations of $E$. spinidens methanolic extract (black bars) or acyclovir (gray bars) were added to HSV-1 infected Vero cells after 1 $\mathrm{h}$ of infection. Inhibition percentage was evaluated by MTS assay after 3 days of incubation at $37^{\circ} \mathrm{C}$. Each bar represents the Mean \pm SE of three independent experiments

To analyze the dose-dependent antiviral activity, HSV-1 infected Vero cells were treated with various concentrations of the crude methanolic extract of E. spinidens in DMSO. Acyclovir and DMSO $(0.1 \%)$ were used as positive and negative control, respectively. The results revealed that the crude methanolic extract, at 5 $\mathrm{mg} / \mathrm{mL}$ concentration, exhibited about $55 \%$ inhibition against HSV-1 replication (Figure 2). Also, it was shown that at concentrations between 0.07 to $5 \mathrm{mg} / \mathrm{mL}$, there was a good correlation between the crude extract concentration and HSV-1 inhibition rate.

\section{DISCUSSION}

The results of this study showed that the crude methanolic extract of $E$. spinidens possess in vitro anti-HSV-1 activity with SI value of 14.917. Our findings of time course analysis experiments also revealed that the extract exhibited the highest inhibition against HSV-1 infection within $2.0 \mathrm{~h}$ post-infection. This may indicate that the extract probably interferes with post-absorption and early stages of HSV-1 replication. Similarly, it has been reported that the crude methanol extract of Mallotus peltatus leaves and Cuminum cyminum L seeds inhibited HSV-1 replication in the early stage and adsorption, respectively $[21,22]$. These results, together, might indicate that some herbal extracts are able to interact with this virus in the intracellular stages of replication. The results of dose-dependent experiments, carried out in this study, in consistent with the results of some other reports [23,24] may indicate that anti-HSV-1 activity of the crude methanolic extract of $E$. spinidens is dose dependent. It has been reported that flavonoids, terpenoid, and saponins are the main active components of Euphorbia genus which are highly extracted by methanol and that the antiviral effect of this genus is due to these secondary metabolites [14,25-27]. Thus, inhibition of HSV-1 replication seen in the present study may probably be due to the action of these secondary metabolites of $E$. spinidens.

\section{CONCLUSION}

Based on our results, crude methanol extract of E. spinidens exhibits anti HSV-1 activity. This is probably due to the inhibition of early viral replication and may be dose-dependent.

\section{ACKNOWLEDGEMENT}

This work is derived, in part, from the MSc thesis of the second-named author and financially supported by the Research Deputy of Shahrekord, Iran. Special thanks go to $\mathrm{Dr}$ Teymori of Virology Sciences, Department of Virology, Tarbiat Modares University, Tehran, Iran) for his help, including provision of HSV-1 (Strain KOS).

\section{REFERENCES}

1. Vijayan P, Raghu C, Ashok G, Dhanaraj SA, Suresh B. Antiviral activity of medicinal plants of Nilgiris. Indian $J$ Med Res 2004; 120: 24-29.

2. Villarreal EC. Current and potential therapies for the treatment of herpes virus infections. Prog Drug Res 2001; 60: 185-228. 
3. Rafieian-Kopaei M, Sewell RD. The history and ups and downs of herbal medicines usage. $J$ HerbMed Pharmacol. 2014; 3(1): 1-3.

4. Karimi A, Moradi M-T. Total phenolic compounds and in vitro antioxidant potential of crude methanol extract and the correspond fractions of Quercus brantii L. acorn. J HerbMed Pharmacol 2015; 4(1): 35-39.

5. Karimi A, Moradi MT, Saeedi M, Asgari S, RafieianKopaei M. Antiviral activity of Quercus persica L.: High efficacy and low toxicity. Adv Biomed Res 2013; 2: 36

6. Moradi MT, Rafieian-Koupaei M, Imani-Rastabi R, Nasiri J, Shahrani M, Rabiei Z, et al. Antispasmodic effects of yarrow (Achillea millefolium L.) extract in the isolated ileum of rat. Afr J Tradit Complement Altern Med 2013; 10(6): 499-503.

7. Moradi M-T, Karimi A, Alidadi S, Gholami-Arjenaki M. In vitro anti-herpes simplex type-1 activity, antioxidant potential and total phenolic compounds of pomegranate (Punica granatum L.) peel extract. J Chem Pharm Res 2015; 7(8): 82-88.

8. Asgary $S$, Kelishadi R, Rafieian-Kopaei M, Najafi S, Najafi $M$, Sahebkar $A$. Investigation of the lipidmodifying and anti-inflammatory effects of Cornus mas L. supplementation on dyslipidemic children and adolescents. Pediatr Cardiol 2013; 34(7): 1729-1735.

9. Asgary S, Sahebkar A, Afshani MR, Keshvari M, Haghjooyjavanmard $S$, Rafieian-Kopaei M. Clinical evaluation of blood pressure lowering, endothelial function improving, hypolipidemic and anti-inflammatory effects of pomegranate juice in hypertensive subjects. Phytother Res 2014; 28(2): 193-199.

10. Rafieian-Kopaei M, Asgary S, Adelnia A, Setorki M, Khazaei M, Kazemi S, et al. The effects of cornelian cherry on atherosclerosis and atherogenic factors in hypercholesterolemic rabbits. J Med Plants Res 2011; 5(13): 2670-2676.

11. Bahmani M, Zargaran A, Rafieian-Kopaei M, Saki K. Ethnobotanical study of medicinal plants used in the management of diabetes mellitus in the Urmia, Northwest Iran. Asian Pac J Trop Med 2014; 7s1: S348354.

12. Delfan B, Bahmani M, Hassanzadazar H, Saki K, Rafieian-Kopaei M. Identification of medicinal plants affecting on headaches and migraines in Lorestan Province, West of Iran. Asian Pac J Trop Med 2014; 7s1: S376-379

13. Nasri $H$, Shahinfard N, Rafieian M, Rafieian S, Shirzad $M$, Rafieian M. Turmeric: A spice with multifunctional medicinal properties. J Herb Med Pharmacol 2014; 3(1): 5-8.

14. Jassbi AR. Chemistry and biological activity of secondary metabolites in Euphorbia from Iran. Phytochemistry 2006; 67: 1977-1984.
15. Appendino G, Spagliardi $P$, Ballero M, Seu $G$. Macrocyclic diterpenoid from Euphorbia hyberna. Fitoterrapia 2000; 73: 756-762.

16. Yoshida T, Amakura Y, Liu Z, Okuda T. Three new hydrolyzable tannins and a polyphenol glucoside from Euphorbia humifusa. Chem Pharm Bull 1994; 42: 18031807.

17. Singla AK, Pathak K. Topical antiflammatory effects of Euphorbia prostrate on carrageenan induced footpad oedema in mice. J Ethnopharmacol 1990; 29: 291-294.

18. Qing-Wen Shi, Xiao-Hui Su, Hiromasa K. Chemical and pharmacological research of the plants in genus Euphorbia. Chem Rev 2008; 108: 4295-4327.

19. Folin O, Ciocalteu V. On tyrosine and tryptophane determinations in proteins. J biol Chem. 1927; 73(2): 627-650.

20. Sharafati-chaleshtori $R$, Rafieian-kopaei R, Mortezaei $S$, Sharafati-chaleshtori A, Amini E. Antioxidant and antibacterial activity of the extracts of Echinophora platyloba D.C. Afr J Pharm Pharmacol 2012; 6: 26922695.

21. Bag P, Chattopadhyay D, Mukherjee H, Ojha D, MandalMamta N, Sarkar C, Gobardhan T, Sekhar-Chakraborti $D$. Anti-herpes virus activities of bioactive fraction and isolated pure constituent of Mallotus peltatus: an ethnomedicine from Andaman islands. J Virol 2012; 9: 98-105.

22. Motamedifar M, Ghafari N, Talezadeh-Shirazi M. The effect of Cumin seed extracts against herpes simplex virus type 1 in Vero cell culture. Int J Mol Sci 2010; 35: 304-309.

23. Betancur-Galvis LA, Morales GE, Forero JE, Roldan J. Cytotoxic and antiviral activities of Colombian medicinal plant extracts of the Euphorbia genus. Mem Inst Oswaldo Cruz Rio de Janeiro 2002; 97: 541-546.

24. Sudhakar $M$, Rao-Ch V, Rao PM, Raju DB, Venkateswarlu Y. Antimicrobial activity of Caesalpinia pulcherrima, Euphorbia hitra and Asystasia gangeticum. Fitoterapia 2006; 77: 378-380.

25. Shi QW, Su XH, Kiyota H. Chemical and pharmacological research of the plants in genus euphorbia. Chem Rev 2008;108:4295-4327

26. Ghanadian M, Akhavan A, Ayatollahi A, MohammadiKamalabadi M, Abdella O. Triterpenes from Euphorbia spinidens with their immunomodulatory activity. Res Pharm Sci 2013; 8: 205-210.

27. Mothana $R$, Lindequist $U$, Geraenert $R$, Bednarski $P$. Studies of the in vitro anticancer antimicrobial and antioxidant potentials of selected Yemeni medicinal plants from the Island Soqotra. BMC Complement Altern Med 2009; 9:7-23. 